\title{
PELAKSANAAN PEMILIHAN KEPALA DESA DALEMAN KECAMATAN KEDUNGDUNG KABUPATEN SAMPANG
}

\author{
Habibi \\ Daleman Kedungdung Sampang Madura | habibi45@gmail.com
}

\begin{abstract}
This article discusses about a political shari'atis view on the implementation of the village's head election in DalemanKedungdung-Sampang. The results of the research conclude that the mechanism of the village's head election starting from the formation of the committee election, the candidates crawl, the campaign, the voice collecting and counting, and the announcement and the establishment of elected candidates. The election committee has done them according to the procedures and not in conflict with the political shariah as well as the Regional Regulation of Sampang No. 5 year 2006 concerning the procedures for the nomination, election, appointment and dismissal of the head of the village. However, in its implementation, there was one of the candidates practiced money politics and intimidation where the money politics is banned by Islamic law, while intimidation violates the basic values of the political shariah about welfare. It is not also justified under article I 5 of Regional Regulation No. 5, article 15 year 2006 of Sampang. In addition to the money politics and intimidation practice, the village's head election is also tinged with gambling which is obviously forbidden in Islam. However, the Regional Regulation has not clearly set those practices yet.
\end{abstract}

Keywords: Village's head election, political shari'ah.

Abstrak: Artikel ini membahas tentang tinjauan siyâsah shariyyah terhadap pelaksanaan pilkades di Desa Daleman Kecamatan Kedungdung Kabupaten Sampang. Setelah dilakukan penelitian secara komprehensif, ditemukan bahwa proses dan mekanisme pemilihan Kepala Desa Daleman mulai dari pembentukan Panitia Pemilihan Kepala Desa (P2KD), penjaringan bakal calon, kampanye, pemunggutan dan perhitungan suara, sampai pengumuman dan penetapan calon terpilih, panitia pemilihan sudah melakukan prosedur 
yang tidak bertentangan dengan syara' atau siyâsah syar'iyyah (Sistem Politik Islam) dan Peraturan Daerah (PERDA) Kabupaten Sampang No.5 Tahun 2006 tentang tata cara pencalonan, pemilihan, pelantikan dan pemberhentian kepala desa. Namun dalam pelaksanaan ini salah satu calon melakukan praktik politik uang dan intimidasi, yang mana politik uang ini dilarang menurut syara', sedangkan intimidasi menyalahi nilai dasar siyâsah shar'iyyah tentang kemaslahatan dan hal ini juga tidak dibenarkan dalam Pasal 15 Peraturan Daerah Kab.Sampang No.5 Tahun 2006. Selain praktik politik uang dan intimidasi, Pilkades juga diwarnai dengan perjudian yang jelas dilarang dalam Islam, namun dalam Perda tersebut belum diatur secara jelas tentang larangan praktik perjudian dalam pelaksanaan pilkades.

Kata Kunci: Pemilihan kepala desa, siyasah, shar'iyyah.

\section{Pendahuluan}

Penyelenggaraan otonomi daerah merupakan salah satu upaya strategis dalam memberikan kewenangan dan keleluasaan membentuk dan melaksanakan kebijakan menurut prakarsa dan aspirasi masyarakat. Otonomi daerah, sebenarnya secara konsep mengandung prinsip atas asas desentralisasi dalam wujud otonomi yang luas, nyata dan bertanggung jawab, kemudian dirumuskan dalam kebijakan otonomi daerah yang sifatnya menyeluruh dan dilandasi oleh prinsip-prinsip dasar demokrasi, kesetaraan dan keadilan disertai untuk kesadaran akan keaneka ragaman kehidupan kita bersama sebagai bangsa dalam semangat Bhineka Tunggal Ika. Otonomi daerah dan demokrasi merupakan dua konsep yang harus berjalan terpadu untuk menciptakan tatanan pemerintahan yang ideal, mulai dari tingkat pusat sampai tingkat desa. ${ }^{1}$

Sejak diberlakukannya otonomi daerah, desa diberi kebebasan penuh untuk mengelola rumah tangganya, sebagaimaana di uraikan dalam UU No.32 Tahun 2004 Tentang Pemerintah Daerah yang menyebutkan Desa adalah kesatuan

Hanif Nurcholis, Pertumbuhan \& Penyelenggaraan Pemerintahan Desa (Jakarta: Erlangga, 20II) 64 .

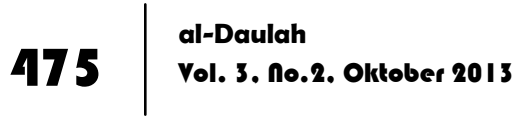


masyarakat hukum yang memiliki batas-batas wilayah yang memiliki wewenang untuk mengatur dan mengurus kepentingannya sendiri berdasarkan asal usul dan adat istiadat setempat yang diakui dan dihormati dalam sistem Pemerintahan Negara Kesatuan Republik Indonesia (NKRI). ${ }^{2}$

Terjadinya pergantian dari orde baru kepada orde reformasi sejak 1998 telah menyebabkan kemunculan kembali kekuatankekuatan politik desa. Masyarakat desa mengalami proses partisipasi politik yang termobilisasi oleh faktor birokrasi pemerintah desa. Dan yang paling penting adalah ketika dimunculkannya perubahan paradigma pembangunan dari orientasi struktural birokrasi sentralistik berubah menjadi sistem birokrasi desentralistik. ${ }^{3}$

Adanya kebijakan otonomi daerah melalui Undang-Undang No.22 Tahun 1999 mengisyaratkan pemerintah dan masyarakat di daerah dipersilahkan mengurus rumah tangganya sendiri secara bertanggung jawab. Pemerintah pusat tidak lagi menguasai/mendominasi mereka. Peran pemerintah pusat dalam konteks desentralisasi ini adalah melakukan supervisi, memantau, mengawasi dan mengevaluasi pelaksanaan otonomi daerah. ${ }^{4}$

Negara Kesatuan Republik Indonesia merupakan suatu negara demokrasi. Adapun demokrasi yang dipraktekkan di Indonesia ini didasarkan pada prinsip musyawarah dan mufakat atau prinsip kekeluargaan yang bersumber pada kepribadian dan pandangan hidup bangsa Indonesia. Salah satu bentuk dari demokrasi di tingkat desa yaitu pemilihan Kepala Desa yang merupakan wujud dari pelaksanaan demokrasi langsung. ${ }^{5}$

Disamping itu kehadiran Badan Permusyawaratan Desa (BPD) mempunyai peranan atau kedudukan yang penting yaitu membuat peraturan desa, menampung dan menyalurkan aspirasi

\footnotetext{
2 UU No.32 Tahun 2004 Tentang Pemerintah Daerah (Jakarta : Sinar Grafika, 2005) 4-5.

${ }^{3}$ Sujamto, Otonomi Birokrasi Partisipasi (Semarang: Dahara Prize, 1992), 51.

${ }^{4}$ Haris Syamsudin, Desentralisasi \& Otonomi Daerah (Jakarta: LIPI Press, 2007), 9.

${ }^{5}$ Meriam Budiardjo, Demokrasi di Indonesia (Jakarta: Gramedia Pustaka Utama, 1996), 243.
} 
masyarakat, serta melakukan pangawasan terhadap penyelenggaraan pemerintahan desa, lembaga ini merupakan perwujudan demokrasi dalam penyelenggaraan pemerintahan desa sebagai unsur penyelenggaraan pemerintahan desa, dalam hal ini proses Pilkades (Pemilihan Kepala Desa). ${ }^{6}$

Dalam kajian siyāsah syar'iyyah pengangkatan pejabat untuk mengurusi perkara kaum muslimin ini mutlak harus dilaksanakan. Oleh karena itu, perlu dilakukan suksesi selektif bagi orang-orang yang akan dipilih untuk memangku jabatan tersebut karena jabatan itu adalah sebuah amanat yang harus dilaksanakan sesuai dengan misi yang di embannya, sebagaimana sabda Nabi Muhammad SAW. kepada Abu Dzar al-Ghifari r.a.

"Sesungguhnya ia adalah amanat. Dan pada hari kiamat ia merupakan kehinaan dan penyesalan, kecuali bagi mereka yang mengembalikannya sesuai dengan haknya dan melaksanakan apa yang menjadi tuntutannya" (H.R.Muslim). ${ }^{7}$

Sebagai sarana mewujudkan kedaulatan rakyat di desa, suksesi kepala desa secara demokratis merupakan embrio dimana partisipasi masyarakat desa yang otonom itu dapat segera terwujud menjadi kenyataan. Upaya melakukan revitalisasi terhadap budaya demokrasi yang sempat terabaikan khususnya selama masa orde baru yang tentunya dengan pendekatan dialogis dan partisipatoris. Dengan demikian, munculah berbagai macam produk kebijakan yang ditujukan untuk menata penyelenggaraan pemerintahan desa, dimana berdasarkan prinsip desentralisasi, sebagian besar kewenangan penataan penyelenggaraan pemerintahan desa diserahkan kepada pemerintahan di level Kabupaten. Berdasarkan kewenangan ini, maka Pemerintah Kabupaten menjadi ujung tombak kewajiban pemerintah pusat untuk menata desa dan salah satu dari program perencanaan otonomi desa yang masih dibawah lingkup kabupaten adalah

${ }^{6}$ UU No.32 Tahun 2004 Tentang Pemerintahan Daerah (Jakarta : Sinar Grafika, 2005), I 19.

${ }^{7}$ Ibnu Taimiyah, Siyasah Syar'iyah (Surabaya: Risalah Gusti, 1995), 5. 
penanaman pemahaman tentang politik ditingkat desa yakni dengan diadakannya pemilihan Kepala Desa. ${ }^{8}$

Pemilihan kepala desa di Desa Daleman Kec. kedundung, dipilih secara langsung oleh warga desa setempat, dalam praktek ini terjadi kompetisi yang bebas, partisipatif, langsung dengan prinsip One Person One Vote $^{9}$, namun akhir-akhir ini sesuatu yang diharapkan dari pilkades ini tidak sesuai dengan yang diinginkan, biasanya, beberapa hari sebelum pemilihan kepala desa, terdapat peraktik intimidasi dan pembagian uang terhadap masyarakat yang memiliki hak pilih, hal ini berlangsung hingga salah satu calon yang di unggulkan menang dan ini dilakukan oleh tim sukses masing-masing calon. Selain itu pelaksanaan pilkades juga dibuat ajang perjudian dengan omset ratusan juta rupiah. Realita yang ada dilapangan menunjukkan kegiatan tersebut sering terjadi ketika ada pelaksanaan pilkades sehingga masyarakat resah ketika akan ada pemilihan kepala desa.

Dari pemaparan diatas, maka kemudian penulis tertarik untuk melakukan kajian mengenai hal tersebut.

\section{Pemilihan Kepala Desa}

Desa merupakan bagian dari sebuah kecamatan. Setiap desa dipimpin oleh seorang kepala desa. Kepala desa dipilih langsung oleh masyarakat di desa tersebut dari calon yang memenuhi syarat. Syarat dan tata cara pemilihannya diatur oleh peraturan daerah yang berpedoman pada peraturan pemerintah.

Dalam UUD 1945, baik sebelum maupun setelah amandemen tidak ada satu ketentuanpun yang secara eksplisit mengatur tentang pemilihan kepala desa. Bahkan pengaturan tentang Desapun secara eksplisit juga tidak ditemukan dalam UUD 1945, walaupun sebenarnya Desa dan Sistem Pemerintahanya mempunyai peranan sangat penting dalam pembangunan NKRI,

${ }^{8}$ Bayu Surianingrat, Pemeritahan Administrasi Desa dan Kelurahan (Jakarta: Rineka Cipta, 1992), 61.

${ }_{9}^{9}$ Miftah Thoha, Birokrasi \& Politik di Indonesia (Jakarta: Rajawali Pers. 2003), 102. 
mengingat semua masyarakat bertempat tinggal di desa atau dengan sebutan istilah lainnya. Dan pemerintahan desa-lah yang bersentuhan langsung dengan denyut nadi kehidupan masyarakat.

Istilah desa dalam UUD 1945 sebelum amandemen dapat kita jumpai dalam Pasal 18 dan penjelasannya, yang berbunyi sebagai berikut :

"Pembagian daerah Indonesia atas daerah besar dan kecil, dengan bentuk susunan pemerintahannya ditetapkan dengan undang-undang dengan memandang dan mengingati dasar permusyawaratan dalam sistem pemerintahan Negara, dan hak asal-usul dalam daerah yang bersifat istimewa".

Dan Pasal 18 Undang - Undang Dasar 1945 penjelasan II, berbunyi :

“Dalam territoir Negara Indonesia terdapat kurang lebih 250 "Zelbesturendelandschappen" dan "Volkgemenschappen" seperti desa di Jawa dan Bali, nagari di Minangkabau, dusun dan marga di Palembang dan sebagainya. Daerah-daerah itu mempunyai susunan asli dan oleh karenanya dapat dianggap sebagai daerah yang bersifat istimewa ".

Sedangkan setelah amandemen, Pasal 18 ayat (1) UUD 1945 berbunyi :

“Negara kesatuan Republik Indonesia di bagi atas daerahdaerah propinsi, dan daerah provinsi itu dibagi atas kabupaten dan kota, yang tiap tiap provinsi, kabupaten dan kota itu mempunyai pemerintahan daerah, yang diatur dengan undang-undang"

Berdasarkan Pasal 18 diatas, maka kemudian dibentuklah Undang-Undang Nomor 32 tahun 2004 tentang Pemerintahan Daerah, yang dalam Pasal 200 ayat (1) dibentuklah Pemerintahan Desa, yang berbunyi:

"Dalam Pemerintahan daerah kabupaten / kota dibentuk pemerintahan desa yang terdiri dari pemerintah desa dan badan permusyawaratan desa." 
Desa dan/atau Pemerintahan Desa dipimpin oleh seorang Kepala Desa yang dipilih langsung dari dan oleh penduduk desa setempat yang memenuhi persyaratan. Hal tersebut diatur dalam Pasal 203 ayat (1) UU No. 32 tahun 2004 tentang Pemerintahan Daerah, yang berbunyi :

"Kepala desa sebagaimana dimaksud dalam Pasal 202 ayat (1) dipilih langsung oleh dan dari penduduk desa warga negara Repablik Indonesia yang syarat selanjutnya dan tata cara pemilihannya diatur dengan Perda yang berpedoman kepada Peraturan Pemerintah."

Selanjutnya dalam Peraturan Pemerintah Nomor 72 tahun 2005 tentang Desa, di Bagian Keempat diatur tentang Pemilihan Kepala Desa, yaitu mulai dari Pasal 43 s/d Pasal 54. Dalam Pasal 46 PP No. 72 tahun 2005 tersebut diatur sebagai berikut :

(1) Kepala Desa dipilih langsung oleh penduduk desa dari calon yang memenuhi syarat.

(2) Pemilihan Kepala Desa bersifat langsung, umum, bebas, rahasia, jujur dan adil.

(3) Pemilihan Kepala Desa dilaksanakan melalui tahap pencalonan dan tahap pemilihan.

Sedangkan untuk pemilih diatur dalam Pasal 45, yang berbunyi sebagai berikut :

"Penduduk desa Warga Negara Republik Indonesia yang pada hari pemungutan suara pemilihan kepala desa sudah berumur 17 (tujuh belas) tahun atau sudah/pernah kawin mempunyai hak memilih."

Adapun untuk pengaturan lebih lanjut tentang Tata Cara Pemilihan Kepala Desa akan diatur dengan Peraturan Daerah Kabupaten / Kota yang bersangkutan. ${ }^{10}$

Kepala desa bukanlah seorang pegawai negeri sipil. Masa jabatan kepala desa adalah enam tahun. Ia dapat dipilih kembali 
hanya untuk satu kali masa jabatan berikutnya. Sesudah itu, ia tidak boleh lagi mengikuti pemilihan calon kepala desa.

Seorang Kepala desa dilantik oleh bupati/ wali kota, paling lambat tiga puluh hari setelah dinyatakan terpilih. Kepala desa mendapatkan gaji (upah) bukan dari pemerintah, tetapi dari hasil pengolahan tanah yang diserahkan untuk diolah. Di daerah Jawa dikenal dengan tanah "bengkok" atau tanah "carik". Setelah masa jabatannya habis, tanah itu harus dikembalikan kepada pemerintah. Dengan demikian, kepala desa tidak mendapatkan uang pensiun seperti Pegawai Negeri Sipil (PNS).

a. Ketentuan Umum Pemilihan Kepala Desa

1) Kepala Desa dipilih langsung oleh Penduduk Desa dari Calon yang memenuhi syarat;

2) Pemilihan bersifat langsung, umum, bebas, rahasia, jujur dan adil;

3) Pemilihan Kepala Desa melalui tahap pencalonan dan pemilihan;

4) Pencalonan dan Pemilihan Kepala Desa apabila tidak dapat dilaksanakan tepat waktu, maka Camat dapat mengajukan kepada Bupati untuk memperpanjang waktu selamalamanya 1 (satu) bulan dengan ketentuan Kepala Desa yang bersangkutan tetap melaksanakan tugasnya; dan

5) Apabila perpanjangan waktu belum bisa dilaksanakan, Camat mengusulkan Calon Penjabat Kepala Desa kepada Bupati. ${ }^{11}$

b. Hak Memilih Dan Dipilih Serta Persyaratan Bakal Calon Yang dapat memilih dan dipilih dalam Pemilihan Kepala Desa adalah Penduduk Desa setempat warga Negara Republik Indonesia.

1) Syarat- syarat yang dapat memilih iyalah: 
a) Terdaftar secara sah sebagai penduduk desa yang bersangkutan sekurang-kurangnya 6 bulan dengan tidak terputus-putus;

b) Sudah berusia 17 (tujuh belas) tahun dan atau telah pernah menikah pada saat pencoblosan dilaksanakan;

c) Tidak dicabut hak pilihnya berdasarkan Keputusan Pengadilan yang telah mempunyai kekuatan hukum tetap;

d) Tidak pernah terlibat baik langsung maupun tidak langsung dalam suatu kegiatan yang menghianati Negara Kesatuan Republik Indonesia yang berdasarkan Pancasila dan Undang-undang Dasar 1945.

Sedangkan yang dapat dipilih sebagai Kepala Desa adalah penduduk desa Warga Negara Republik Indonesia dengan syarat-syarat:

2) Syarat-syarat yang dapat dipilih menjadi Kepala Desa ialah :

a) Bertaqwa kepada Tuhan Yang Maha Esa;

b) Setia kepada Pancasila sebagai Dasar Negara, UndangUndang Dasar Negara Republik Indonesia Tahun 1945 dan Kepada Negara Kesatuan Republik Indonesia serta Pemerintah;

c) Tidak pernah terlibat langsung atau tidak langsung dalam kegiatan yang menghianati Pancasila dan UUD 1945, atau kegiatan organisasi terlarang lainnya;

d) Berpendidikan sekurang-kurangnya Sekolah Lanjutan Tingkat Pertama dan/atau sederajat;

e) Pada saat pendaftaran berusia sekurang-kurangnya 25 (dua puluh lima) tahun;

f) Sehat jasmani dan rohani;

g) Nyata-nyata tidak terganggu jiwa/ingatannya;

h) Berkelakuan baik, jujur dan adil;

i) Tidak pernah dihukum penjara karena melakukan tindak pidana kejahatan dengan hukuman paling singkat 5 tahun atau lebih yang dibuktikan dengan Surat Keterangan Pengadilan Negeri; 
j) Tidak dicabut Hak Pilihnya berdasarkan keputusan pengadilan yang mempunyai kekuatan hukum tetap;

k) Mengenal desanya dan dikenal oleh masyarakat desa setempat;

1) Bersedia dicalonkan menjadi Kepala Desa;

m) Terdaftar secara sah sebagai penduduk dan bertempat tinggal tetap di Desa yang bersangkutan sekurangkurangnya 2 tahun terakhir dengan tidak berputusputus, kecuali Putra Desa yang berada di luar desa tersebut.

3) Belum pernah menjabat sebagai Kepala Desa paling lama 10 (sepuluh) tahun atau 2 (dua) kali masa jabatan.

4) Pegawai Negeri Sipil dan anggota TNI/POLRI dapat mencalonkan diri sebagai Kepala Desa apabila memenuhi syarat-syarat sebagaimana dimaksud pada ayat (1) dan ayat (2) serta syarat-syarat lain yang sudah ditentukan oleh induk instansi masing-masing (anggota TNI/POLRI harus mendapat rekomendasi/ijin dari Instansi induknya.

5) Bagi Pegawai Negeri Sipil dan anggota TNI/POLRI yang diangkat dan ditetapkan menjadi Kepala Desa dibebaskan dari jabatan organiknya tanpa kehilangan statusnya sebagai Pegawai Negeri Sipil atau anggota TNI/POLRI.

6) Calon Kepala Desa Terpilih sebagai Kepala Desa, terhitung sejak tanggal pelantikannya harus bertempat tinggal tetap di Desa yang bersangkutan.

7) Bagi Kepala Desa yang akan mencalonkan kembali sebagai Kepala Desa diwajibkan mengajukan cuti kepada Bupati melalui Camat selambat-lambatnya 4 (empat) bulan sebelum masa jabatannya berakhir dan Penjabat Kepala Desa tidak berhak mencalonkan diri sebagai Kepala Desa.

Dalam pemilihan Kepala Desa, setiap penduduk desa setempat warga Negara Republik Indonesia yang telah memenuhi persyaratan sebagaimana dimaksud pada Pasal 7, dan telah disahkan sebagai pemilih mempunyai hak pilih, selanjutnya untuk 
hadir pada pelaksanaannya dan tidak boleh diwakilkan kepada siapapun dan dengan alasan apapun. ${ }^{12}$

Sebagaimana telah diuraikan tentang pentingnya kedudukan kepala desa, maka proses pergantian kepala desa ini tentunya merupakan peristiwa besar bagi masyarakat desa. Artinya penting pergantian kepala desa tampak jelas dari reaksi-reaksi yang muncul yang dilakukan penduduk desa pada saat proses pemilihan kepala desa berlangsung.

Hasil penelitian yang dilakukan oleh Balai Penelitian Pers dan Pendapatan Umum (BP3U) Yogyakarta mengungkapkan bahwa selama berlangsungnya pemilihan kepala desa telah terjadi kasuskasus seperti : adanya baikot dari pemilih, adanya calon tunggal yang tidak terpilih karena masyarakat (pemilih) justru memberikan suaranya untuk kotak kosong, adanya unsur perjudian dan adanya calon favorit yang tidak lulus ujian tulis (Permadi, 1988 : 13). Kasus-kasus itu diinventarisasi melalui pemberitaan 3 surat kabar di Yogyakarta dan 1 surat kabar di jawa tengah selama bulan juni 1988. Dengan demikian jelas arti penting pergantian kepala desa, sebagaiamana terlihat dari proses pemilihan kepala desa, adalah sama pentingnya dengan keberadaan kepala desa itu sendiri bagi masyarakat pedesaan.

Untuk menjadi calon kepala desa sebelum pemilihan dilangsungkan hal apa yang dianggap penting yang harus dilakukan, serta mengapa suatu tindakan tertentu itu dilakukan. Misalnya, adanya kecendrungan umum bahwa seorang calon kepala desa selalu berhubungan dengan orang-orang tua (dukun) dalam usahanya memenangkan pemilihan. Untuk memenangkan persaingan dengan calon-calon lain, maka masing-masing calon akan menggunakan cara-cara tertentu untuk memproleh dukungan suara baik dari warga desa pada umumnya maupun dari pendukung calon-calon saingannya. ${ }^{13}$

\footnotetext{
${ }^{12}$ PERDA Kab.Sampang No.5 Tahun 2006.

${ }^{13}$ Suharni, Sartono Kartodirdjo, Pesta Demokrasi di Pedesaan: Studi Kasus Pemilihan Kepala Desa di Jawa Tengah dan D/Y (Yogyakarta: Aditya Media, 1992), 23.
} 


\section{Persiapan Pemilihan Kepala Desa Daleman}

Pemilihan kepala desa daleman diperoses 4 (empat) bulan sebelum berakhirnya masa jabatan kepala desa dan proses ini dimulai dengan rapat Badan Permusyawaratan Desa (BPD). yang terdiri dari Ketua, pemangku adat, golongan profesi, pemuka agama dan tokoh atau pemuka masyarakat lainya untuk membentuk Panitia Pemilihan Kepala Desa (P2KD), dalam rapat tersebut selain pembentukan struktur panitia, juga membahas tentang persiapan pelaksanaan pemilihan kepala desa.

Struktur Badan Permusyawaratan Desa (BPD) Desa Daleman :

Ketua : Abd. Hadi

Wakil Ketua : KH. Umar Hadi

Sekretaris : KH. Maksum

Anggota : Uts. Arifin, Syukkur, Abd. Karim dan Baharuddin. ${ }^{14}$

Dari hasil rapat tersebut terbentuklah Panitia Pemilihan Kepala Desa (P2KD) yang terdiri dari : ketua, wakil ketua, sekretaris, wakil sekretaris, bendahara dan anggota.

Adapun Susunan panitia (P2KD) Desa Daleman tersebut sebagai berikut :

$\begin{array}{ll}\text { Ketua } & \text { : Ali Yanto } \\ \text { Wakil Ketua } & \text { : H.Sulthon } \\ \text { Sekretaris } & \text { :Syafi'i } \\ \text { Wakil Sekretaris } & \text { : Maksum } \\ \text { Bendahara } & \text { : Agus Muktamar } \\ \text { Anggota } & \text { : Farid, Fathur, Sholeh, Ust.Jasiman, Ust. } \\ & \text { Rodin, Arafik, Sholihin, Ismail, Shohib, } \\ & \text { Mukarrom, Abd. Yakin, Hardi dan H. } \\ & \text { Ilyas. }^{15}\end{array}$

Setelah P2KD terbentuk selanjutnya panitia tersebut memulai tugasnya antara lain :

\footnotetext{
${ }^{14}$ Ketua P2KD (aliyanto) Data, Sampang, 10 Mei 2012.

${ }^{15}$ Ketua P2KD (aliyanto) Data, Sampang, 10 Mei 2012.
} 
a. Merumuskan anggaran dana dalam pelaksanaan pemilihan kepala desa

b. Rapat Koordinasi P2KD dengan perwakilan dari Kecamatan Kedungdung untuk penyempurnaan susunan panitia.

c. Penyusunan piket kerja.

Setelah itu panitia mengajukan RAB (Rancangan Anggaran Biaya) pelaksanaan pemilihan kepala desa serta meminta persetujuan RAB oleh anggota yang lain. Dalam rapat ini disepakati beberapa hal yang berkenaan dengan RAB yang antara lain :

a. Anggarana pelaksanaan pemilihan kepala desa

b. Biaya pilkades di bebankan pada masing-masing calon

c. Biaya pilkades juga di bebankan pada APBD Desa, APBD Kabupaten dan swadaya sumbangan dari masyarakat.

Kesimpulan dari hasil rapat ini menyetujui anggaran biaya pelaksanaan pemilihan kepala desa serta penetapan anggaran yang di tetapkan dengan keputusan BPD.

\section{Penjaringan dan Penyaringan Bakal Calon Kepala Desa Daleman}

Setelah persiapan dan anggaran ditetapkan serta disetujui oleh BPD, selanjutnya panitia melakukan penjaringan dan penyaringan bakal calon kepala desa daleman, dalam hal ini panitia memeriksa identitas bakal calon berdasarkan persyaratan yang ditetapkan oleh Panitia Pemilihan berdasarkan Perda Kab. Sampan No.5 Tahun 2006 sebagai Calon Kepala Desa yang berhak dipilih.

Selanjutnya Panitia Pemilihan segera melakukan pengumuman I dan II untuk menjaring Bakal Calon Kepala Desa. Permohonan Pencalonan Kepala Desa diajukan secara tertulis kepada Panitia Pemilihan dengan dilampiri berkas persyaratan yang ditetapkan.

Hasil penjaringan setelah dilengkapi dengan berkas persyaratan kemudian dilakukan penyaringan. sebagaimana 
dimaksud pada Pasal 11 dalam Perda Kab.Sampang No.5 Tahun 2006.

Proses penjaringan Balon Kepala Desa dilakukan dengan memeriksa kelengkapan data persyaratan masing-masing calon antara lain :

a. Bertakwa kepada tuhan Yang Maha Kuasa;

b. Setia dan taat kepada Pancasila sebagai Dasar Negara, Undang-Undang Dasar Negara Republik Indonesia Tahun 1945 dan Kepada Negara Kesatuan Republik Indonesia serta Pemerintah;

c. Tidak pernah terlibat langsung atau tidak langsung dalam kegiatan yang menghianati Pancasila dan UUD 1945, atau kegiatan organisasi terlarang lainnya;

d. Berpendidikan sekurang-kurangnya Sekolah Lanjutan Tingkat Pertama dan/atau sederajat;

e. Pada saat pendaftaran berusia sekurang-kurangnya 25 (dua puluh lima) tahun;

f. Sehat jasmani dan rohani;

g. Nyata-nyata tidak terganggu jiwa/ingatannya;

h. Berkelakuan baik, jujur dan adil;

i. Tidak pernah dihukum penjara karena melakukan tindak pidana kejahatan dengan hukuman paling singkat 5 tahun atau lebih yang dibuktikan dengan Surat Keterangan Pengadilan Negeri;

j. Tidak dicabut Hak Pilihnya berdasarkan keputusan pengadilan yang mempunyai kekuatan hukum tetap;

k. Mengenal desanya dan dikenal oleh masyarakat desa setempat;

1. Bersedia dicalonkan menjadi Kepala Desa;

$\mathrm{m}$. Terdaftar secara sah sebagai penduduk dan bertempat tinggal tetap di Desa yang bersangkutan sekurangkurangnya 2 tahun terakhir dengan tidak berputus-putus, kecuali Putra Desa yang berada di luar desa tersebut. 
Dari proses penjaringan dan penyaringan bakal calon kepala desa daleman terdapat tiga pendaftar yaitu, H.Rois, H.Mat Noto dan Hj.Nor.

\section{Pendataan DPS dan DPT}

Setelah proses penjaringan dan penyaringan bakal calon kepala desa, selanjutnya panitia melakukan pendataan untuk daftar pemilih sementara (DPS) hasil jumlah DPS yang dilakukan oleh P2KD dipersentasikan dalam rapat beserta perwakilan dari kantor kecamatan dan jumlah yang terdaftar sebanyak 6904 peserta DPS, setelah itu hasil kemudian di verifikasi lagi untuk di tetapkan dan selanjunya dibuat daftar pemilih tetap (DPT) yang berhasil dihitung sebanyak 6096 orang pemilih.

Adapun rincian hasil Verifikasi DPT dari masing-masing dusun sebagai berikut:
a. Dusun Kacodur : 1370
b. Dusun Laeran : 1845
c. Dusun Betes : 1377
d. Dusun Kloikoi : $1504^{16}$

Ketentuan pendataan DPS dan DPT didasarkan pada persyaratan yang tertuang dalam Perda Kab. Sampang No.5 Tahun 2006 pasal 7.

Adapun syarat-syarat untuk peserta pemilih antara lain :

a. Terdaftar secara sah sebagai penduduk desa yang bersangkutan sekurang-kurangnya 6 bulan dengan tidak terputus-putus;

b. Sudah berusia 17 (tujuh belas) tahun dan atau telah pernah menikah pada saat pencoblosan dilaksanakan;

c. Tidak dicabut hak pilihnya berdasarkan Keputusan Pengadilan yang telah mempunyai kekuatan hukum tetap;

d. Tidak pernah terlibat baik langsung maupun tidak langsung dalam suatu kegiatan yang menghianati Negara Kesatuan 
Republik Indonesia yang berdasarkan Pancasila dan Undang-undang Dasar 1945.

\section{Kampanye}

Setelah proses pendataan Daftar Pemilih Tetap (DPT) terlaksana, selanjutnya panitia memberi kesempatan kepada masing-masing calon kepala desa untuk melakukan kampanye. Kampanye merupakan proses awal dan yang paling urjen bagi masing-masing calon kepala desa karena kampanye politik merupakan sebuah upaya yang terorganisir bertujuan untuk mepengaruhi proses pengambilan keputusan para pemilih. ${ }^{17}$

Dalam Perda Kab. Sampang No.5 Tahun 2006 dijelaskan bahwasanya Kampanye dilaksanakan hanya 1 (satu) kali yakni selambat-lambatnya 3 (tiga) hari sebelum hari pemilihan. Kampanye sebagaimana dimaksud pada ayat (1) adalah merupakan penyampaian program yang akan dilaksanakan apabila yang bersangkutan terpilih sebagai Kepala Desa. Selanjutnya 2 (dua) hari sebelum hari pemilihan diadakan masa tenang, sehingga dilarang melaksanakan kampanye dalam bentuk apapun. ${ }^{18}$

Kampanye pada prinsipnya merupakan suatu proses kegiatan komunikasi individu atau kelompok yang dilakukan secara terlembaga dan bertujuan untuk menciptakan suatu efek atau dampak tertentu. Rogers dan Storey (1987) mendefinisikan kampanye sebagai "serangkaian tindakan komunikasi yang terencana dengan tujuan untuk menciptakan efek tertentu pada sejumlah besar khalayak yang dilakukan secara berkelanjutan pada kurun waktu tertentu".$^{19}$

Dalam mobilisasi massa/kampanye masing-masing calon kepala desa daleman mempunyai banyak cara, di antaranya memasang poster di pinggir jalan, membagikan stiker dan yang

\footnotetext{
${ }^{17}$ Kampanye, http://id.wikipedia.org (I 5 Juni 20 I 2).

18 PERDA Kab. Sampang No.5 Tahun 2006.

19 Teori Kampanye, http://all-about-theory.blogspot.com ( 5 Juni 20 I 2).
} 
paling preoritas yaitu memberi uang. Pemberian uang dalam kampanye merupakan hal yang sudah di anggap kewajiban bagi masing-masing calon karna ia tahu kelemahan masyarakat pedesaan terletak pada tingkat ekonomi yang rendah sehingga mereka sulit untuk menolaknya dan ini dilakukan dengan 3 (tiga) tahap, tahap pertama, masing-masing calon tak segan-segan mengeluarkan uang dalam acara/hajat warga seperti ketika ada warga yang meninggal dunia atau acara memperingati hari/bulan tertentu, ada juga yang rela memberi fasilitas bagi warga untuk mendapat simpati seperti memperbaiki jalan dan sarana-prasarana yang lain. Tahap kedua, masing-masing bakal calon menempatkan tim di setiap dusun untuk menjaga para orang-orang yang di anggap akan memilihnya (pendukungnya) dalam hal ini tim tersebut akan memberikan uang, yang pada umumnya dikenal dengan istilah uang pengikat. Dan tahap ketiga, yaitu pemberian uang ketika $\mathrm{H}-1$, praktek ini dilakukan pada malam hari dan hal ini yang biasanya disebut serangan fajar. ${ }^{20}$ Namun ada juga yang melakukan kampanye dengan cara membuat warga resah, yaitu dengan cara intimidasi salah satunya seperti menakut-nakuti warga akan kehilangan sapi. ${ }^{21}$

Jika dilihat dari proses kampanye tersebut bisa dilihat bahwa para calon kepala desa merupakan orang kaya dan orang berpengaruh di desa tersebut karena untuk mencalonkan diri sebagai calon kepala desa mereka rela mengeluarkan dana ratusan juta rupiah, semua akan dilakukan oleh para calon hal ini disebabkan anggapan yang selama ini melekat pada masyarakat di beberapa desa yang ada di Madura bahwa kelebun (kepala desa) merupakan posisi yang selalu diperebutkan karena jika orang menjadi kelebun maka dia akan disegani dan dikhormati, disamping itu kepala desa merupakan pimpinan formal yang sangat berpengaruh, oleh karena itu posisi kepala desa mempuniyai status yang tinggi dalam masyarakat perdesaan.

\footnotetext{
${ }^{20}$ Pawi, Wawancara, Sampang, 27 Mei 2012.

${ }^{2}$ Sali, Wawancara, Sampang, 26 Mei 2012.
} 


\section{Pemunggutan dan Perhitungan Suara}

Terhitung 7 (tujuh) hari sebelum pemungutan sura dilaksanakan, Panitia Pemilihan memberitahukan kepada masyarakat tentang akan dilaksanakan Pemilihan Kepala Desa dan mengumumkan secara terbuka nama-nama calon yang berhak dipilih, dan daftar pemilih yang sudah terdaftar di Panitia Pemilihan.

Selanjutnya 2 (dua) hari sebelum pelaksanaan pemungutan suara, Surat Undangan yang memuat tentang hari, tanggal, jam dan tempat pemungutan suara harus sudah diterima oleh pemilih.

Adapun Surat Undangan diberikan nomor urut sesuai nomor urut pada daftar pemilih yang diserahkan. Untuk membuktikan sahnya surat undangan yang dibawa pemilih pada saat akan menggunakan hak pilihnya, Panitia Pemilihan mencocokkan nama yang bersangkutan dengan KTP atau bukti indetitas lain yang dikeluarkan Pejabat yang berwenang.

Selanjutnya sebelum melaksanakan pemunggutan dan perhitungan suara, sesuai Peraturan Daerah Kabupaten Sampan No.5 Tahun 2006 Pasal 16 untuk kelancaran Pelaksanaan Pemilihan, Panitia Pemilihan mempersiapkan dan menyediakan:

a. Surat undangan dan surat suara yang ditandatangani oleh Ketua Panitia Pemilihan dengan cap atau stempel Panitia Pemilihan sebagai tanda yang sah;

b. Kotak surat suara yang jumlah dan besarnya disesuaikan dengan kebutuhan, berikut juga seperangkat kuncinya;

c. Papan pengumuman yang memuat nama calon, jumlah pemilih dan ketentuan quorum;

d. Bilik suara sebagai tempat pemberian suara;

e. Alat pencoblos didalam bilik suara;

f. Papan atau kertas tulis untuk penulisan hasil perhitungan surat suara;

g. Peralatan lainnya yang dianggap perlu.

Pasal 18 menjelaskan bahwa: Pemilihan calon Kepala Desa dihadiri oleh BPD, Panitia Pemilihan, Calon yang berhak dipilih 
dan para pemilih serta Tim Pengawas Tingkat Kecamatan dan Tingkat Kabupaten Sebagai Unsur Perangkat Daerah dan /atau undangan lain yang dianggap perlu; Pemilihan Kepala Desa bersifat langsung, umum bebas, rahasia, jujur dan adil; Setiap hak pilih hanya mempunyai 1 (satu) suara dan tidak boleh diwakilkan dengan alasan apapun; Pemungutan Suara dilaksanakan pada hari, tanggal, jam dan tempat yang telah ditentukan oleh Panitia Pemilihan setelah terlebih dahulu dikonsultasikan kepada Tim Pengawas Kecamatan dan Tim Pengawas Kabupaten.

Setelah semua kebutuhan telah ada maka selanjutnya panitia menjelaskan tata cara pemilihan kepala desa.

Tata Cara Pemungutan Suara:

a. Pemungutan Suara dilaksanakan dengan mencoblos surat suara yang memuat tanda gambar dan /atau foto calon yang berhak dipilih.

b. Pencoblosan surat suara dilaksanakan dalam bilik suara dengan menggunakan alat yang telah disediakan oleh panitia pemilihan untuk memberikan suaranya kepada salah satu orang calon yang berhak dipilih.

c. Pemilih yang keliru mencoblos Surat Suara dapat meminta ganti surat suara yang baru hanya satu kali, setelah menyerahkan surat suara yang keliru kepada Panitia Pemilihan.

d. Setelah surat suara dicoblos pemilih memasukkan surat suara tersebut kedalam kotak suara yang disediakan panitia pemilihan dalam kedaan terlipat.

e. Setelah selesainya pemungutan suara, Panitia Pemilihan meminta kepada masing-masing calon Kepala Desa agar menugaskan 1 (satu) orang pemilih untuk menjadi saksi dalam penghitungan surat suara.

f. Kemudian Panitia Pemilihan membuka Kotak Surat Suara, meneliti setiap lembar surat suara satu-persatu dan membacakan tanda gambar dan atau foto calon Kepala Desa yang mendapat surat suara tersebut serta mencatatnya di 
papan tulis yang ditempatkan sedemikian rupa sehingga dapat diketahui dengan jelas oleh para saksi dan pemilih yang hadir.

g. Pembacaan surat suara dilakukan oleh Panitia Pemilihan secara tegas dan jelas serta ditunjukkan kepada para saksi yang telah ditunjuk oleh calon yang telah dipilih. Setelah pemungutan suara selesai dilaksanakan, Panitia Pemilihan pada hari itu juga menandatangani Berita Acara Pelaksanaan Pemungutan suara bersama sama dengan para calon yang berhak dipilih dan dapat ditambah oleh masing-masing saksi.

Dibalik proses perhitungan ini terdapat kegiatan judi yang cukup meresahkan panitia dan masyarakat, berdasarkan penelusuran penulis para penjudi tersebut merupakan warga dari desa lain yang sengaja datang untuk berjudi namun tak sedikit juga penjudi tersebut adalah masyarakat dese setempat, biasanya kegiatan ini yang menimbulkan kekacauan bahkan carok sehingga panitia mengantisipasi dengan mendatangkan Pihak berwajib untuk menjaga lokasi pemilihan.

\section{Pengumuman dan Penetapan Calon Terpilih}

Setelah penghitungan suara selesai Panitia Pemilihan membacakan perolehan suara masing-masing calon Kepala Desa dan menandatangani berita acara penghitungan suara dengan para saksi dari masing-masing calon Kepala Desa. Laporan Pelaksanaan Pemilihan Kepala Desa dan Berita Acara pemilihan disampaikan oleh Panitia Pemilihan kepada BPD. Selanjutnya BPD menetapkan calon Kepala Desa terpilih dengan keputusan BPD. Keputusan BPD disampaikan kepada Bupati melalui Camat untuk disahkan sebagai Kepala Desa Terpilih dengan Keputusan Kepala Daerah. ${ }^{22}$

Dalam pemilihan kepala desa daleman Kecamatan Kedungdung Kabupaten Sampang di menangkan oleh Hj. Nor nomer urut 3 dengan perolehan 2725 suara.

22 Ketua P2KD (aliyanto), Wawancara, Sampang, 9 Mei 2012.

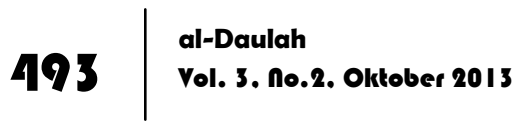


Tinjauan Siyâsah Syar'iyyah terhadap Pelaksanaan Pilkades Desa Daleman Kecamatan Kedungdung Kabupaten Sampang

Bagi masyarakat pedesaan kepala desa bukanlah semata-mata hanya sebagai pemimpin formal tertinggi saja, akan tetapi di anggap juga sebagai bapak bagi seluruh penduduk desa bahkan sering di sepadankan dengan raja. Theodore M.Smith menyebutkan bahwa kepala desa semacam raja kecil di daerahnya (Koentjaaraningrat, 1984a: 198). ${ }^{23}$ Oleh karena itu Pemilihan kepala desa adalah faktor penting dalam kehidupan masyarakat pedasaan.

Sebelum pemilihan dilangsungkan, calon kepala desa akan melakukan hal-hal yang dianggap penting yang harus dilakukan, seperti bersikap baik, tegas dan siaga dalam segala bentuk kegiatan warga, hal ini untuk mencari simpatik dalam memenangkan persaingan dengan calon-calon lain, maka masingmasing calon akan menggunakan cara-cara tertentu untuk memproleh dukungan suara baik dengan menggunakan cara yang terpuji maupun dengan yang cara yang meresahkan warga. Dan tak jarang calon kepala desa yang sudah terpilih menjadi kepala desa menunjukkan sikap yang kurang disukai oleh masyarakat.

Oleh karena itulah Islam memberikan pedoman dalam memilih pemimpin yang baik. Dalam al-Qur'an, Allah SWT memerintahkan ummat Islam untuk memilih pemimpin yang baik dan beriman:

Hai orang-orang yang beriman! Janganlah kamu jadikan bapak-bapak dan saudara-saudaramu menjadi pemimpin-pemimpinmu, jika mereka lebih mengutamakan kekafiran atas keimanan. Dan siapa di antara kamu menjadikan mereka menjadi pemimpin, maka mereka itulah orang2 yang zalim" (At Taubah:23)24

Mayoritas ulama sepakat mengenai keharusan menyelenggarakan siyâsah berdasarkan syara'. Dalam kajian siyâsah

${ }^{23}$ M. Syahbudin Latif, Persaingan Calon Kepala Desa di Jawa (Jakarta : Media Pressindo, 2000), I 2.

${ }^{24}$ Depag, Al-Qur'an dan Terjemah (Bandung: PT. Syamil Cipta Media, 2005) 
syar'iyyah pengangkatan pemimpin untuk mengurusi perkara kaum muslimin ini mutlak harus dilaksanakan karena siyâsah didalamnya mengatur hubungan antara manusia dengan manusia, manusia dengan lembaga, lembaga dengan lembaga, maupun Negara dengan Negara dengan ketentuan syariat Islam. Oleh karena itu perlu dilakukan suksesi selektif bagi orang-orang yang akan dipilih untuk memangku jabatan tersebut karena jabatan itu adalah sebuah amanat yang harus dilaksanakan sesuai dengan misi yang di embannya, sebagaimana sabda Nabi Muhammad SAW. Kepada Abu Dzar al-Ghifari r.a.

"Sesungguhnya ia adalah amanat. Dan pada hari kiamat ia merupakan kehinaan dan penyesalan, kecuali bagi mereka yang mengembalikannya sesuai dengan haknya dan melaksanakan apa yang menjadi tuntutannya" (H.RMuslim). ${ }^{25}$

Memilih pemimpin merupakan bagian dari permasalahan politik dan politik merupakan permasalahan yang sudah ada sejak zaman Nabi SAW. Pada masa Rasulullah hidup, beliau adalah pemimpin umat Islam. Setelah beliau wafat, orang-orang bermusyawarah untuk menentukan pemimpin yang berikutnya, maka terpilihlah Abu Bakar sebagai pemimpin. Umat Islam pun membai'atnya sebagai sikap bahwa mereka akan mengikuti perintahnya. Pada akhir kehidupannya, Abu Bakar memilih Umar bin Khoththob sebagai penggantinya. Sahabat-sahabat senior pun mendukung pilihan Abu Bakar. Ia pun membai'at Umar yang kemudian diikuti oleh kaum muslimin. Umar bin Khaththab memimpin selama sekitar 10 tahun. Sebelum meninggal, dia memilih enam sahabatnya yang mendapat kabar gembira dari Rasulullah bahwa mereka akan masuk surga. Umar berwasiat kepada enam orang ini untuk memilih salah seorang di antara mereka untuk menjadi kholifah. Semua sahabat yang enam samasama enggan untuk menjadi kholifah hingga akhirnya mereka

${ }^{25}$ Ibnu Taimiyah, Siyasah Syar'iyah (Surabaya: Risalah Gusti, 1995), 5.

\begin{tabular}{l|l}
495 & al-Daulah \\
Vol. 3. no.2. Oktober 2013
\end{tabular} 
berhasil memilih Utsman. ${ }^{26}$ Dari uraian ini dapat dipastikan dalam pemilihan pemimpin dalam masa sahabat tidak terdapat ketetapan tentang proses pemilihan pemimpin.

Dalam Islam ada dua sumber hukum, yaitu al-Qur'an dan alSunnah. Kedua sumber hukum dasar ini mengatur bagaimana seharusnya manusia menjalani kehidupan ini. Di dalamnya terdapat perintah-perintah dan larangan-larangan. Setiap perkara akan menimbulkan konsekuensi dari apa yang telah dilakukan dari pada perkara tersebut. Namun, ada perbuatan-perbuatan yang belum diatur secara rinci dalam al-Qur'an dan al-Sunnah. Sebagai contoh, masalah politik dalam proses pemilihan pemimpin. Nabi tidak pernah menetapkan peraturan secara terperinci mengenai pergantian kepemimpinan umat dan kualifikasi pemimpin umat. Salah satu ayat yang oleh sebagian ulama di anggap sebagai dalil yang menunjukkan politik adalah ayat 58-59 surat al-Nisâ':

"Sesungguhnya Allah menyuruh kamu menyampaikan amanat kepada yang berhak menerimanya, dan (menyuruh kamu) apabila menetapkan hukum di antara manusia supaya kamu menetapkan dengan adil. Sesungguhnya Allah memberi pengajaran yang sebaikbaiknya kepadamu. Sesungguhnya Allah adalah Maha mendengar lagi Maha melihat."

"Hai orang-orang yang beriman, taatilah Allah dan taatilah Rasul (Nya), dan ulil amri di antara kamu. kemudian jika kamu berlainan Pendapat tentang sesuatu, Maka kembalikanlah ia kepada Allah (Al Quran) dan Rasul (sunnahnya), jika kamu benar-benar beriman kepada Allah dan hari kemudian. yang demikian itu lebih utama (bagimu) dan lebih baik akibatnya."

Berdasarkan pembahasannya atas ayat 58-59 surat al-Nisâ', Ibnu Taimiyah mengisyartakan unsur-unsur yang terlibat dalam

${ }^{26}$ Al-Usairy, Ahmad. Sejarah Islam: Sejak Zaman Nabi Adam Hingga Abad XX (Jakarta: Akbar Media Eka Sarana. 2003), 20. 
proses siyasah. Ulama menyatakan, bahwa ayat pertama (al-Nisâ': 58) berkaitan dengan pemegang kekuasaan, yang berkewajiban menyampaikan amanat kepada yang berhak dan menghukumi dengan cara yang adil; sedangkan ayat kedua (al-Nisâ':59) berhubungan dengan rakyat, baik militer dan non militer. ${ }^{27}$

Sedangkan dalil dari al-Sunnah yang di isyaratkan pada keharusan mengangkat pemimpin dan keharusan pemimpin bertanggungjawab dalam kepemimpinannya adalah sebagai berikut:

"Dari ibnu Umar r.a., telah bersabda Nabi SAW., setiap kamu itu adalah pemimpin dan setiap pemimpin itu bertanggung jawab atas yang dipimpinnya. Seorang imam yang menjadi pemimpin rakyat bertanggung jawab terhadap rakyatnya dan setiap suami bertanggung jawab atas rumah tangganya". 28

"Dari Abu Hurairah, telah bersabda Rasullah SAW., apabila tiga orang keluar untuk bepergian maka hendaknya salah seorang di antara mereka menjadi pemimpin". ${ }^{29}$

Sebagian besar ulama telah sepakat mengenai kemestian menyelenggarakan siyâsah. Dalam pada itu, mereka pun sependapat tentang keharusan menyelenggarakan siyâsah berdasarkan syara'. Kesepakatan-kesepaktan tersebut tertantum dalam pernyataan Ibnu Qayyim :

"Tidak ada siyasah kecuali yang sesuai dengan syara'."

Dari Ibnu Abid al-Din, sebagaiamana dikutip Ahmad Fathi Bahantsi, memjelaskan: siyas $>a h$ adalah kemaslahatan untuk manusia dengan menunjukkannya kepada jalan yang menyelamatkan, baik di dunia maupun di akhirat. Sedangkan menurut Abd. Wahab Kholaf: siyâsah syar'iyyah merupakan pengurusan hal-hal yang bersifat umum bagi Negara Islam dengan cara yang menjamin perwujudan kemaslahatan dan penolakan kemudaratan dengan tidak melampaui batas-batas

\footnotetext{
${ }^{27}$ Ibnu Taimiyah, Siyasah Syar'iyah (Surabaya: Risalah Gusti, 1995), 4.

${ }^{28}$ HR.Bukhari dan Muslim

${ }^{29}$ HR. Abu Dawud.
} 
syari'ah dan pokok-pokok syari'ah yang kully, meskipun tidak sesuai dengan pendapat ulama-ulama mujtahid. ${ }^{30}$

Pada uraian Ibnu Qayyim ketika mengutip pendapat Ibnu 'Aqil dalam kitab al-Funûn yang menyatakan, siyâsah adalah tindakan yang dengan tindakan itu manusia dapat lebih dekat kepada kebaikan dan lebih jauh dari kerusakan meskipun tindakan itu tidak ada ketetapannya dari Rasul dan tidak ada tuntunan wahyu yang diturunkan. ${ }^{31}$

Dari pernyataan tersebut, Ibnu Qoyyim menjabarkan tentang siyâsah yang mengacu pada syara'. Dalam mekanisme pengendalian dan pengarahan kehidupan umat, terkait keharusan moral dan politik untuk senantiasa mewujudkan keadilan, kerahmatan, kemaslahatan, dan kehikmahan. Hal ini merupakan akibat langsung dari ciri yang melekat pada syari'at Islam. ${ }^{32}$

Berkenaan dengan kajian siyâsah syar'iyyah di atas maka terkait dengan mekanisme pemilihan kepala desa daleman yang diselenggarakan oleh P2KD yang berdasarkan Peraturan Daerah (PERDA) Kabupaten Sampang No.5 Tahun 2006 tidak keluar dari ajaran syara' (sistem politik Islam) namun bersamaan dengan proses tersebut salah satu calon menggunakan politik yang menyalahi syara' seperti money politics (politik uang) yang jelas dilarang dalam Islam sebagaiaman hadis Nabi SAW:

"Allah melaknat orang yang memberi suap dan orang yang menerima suap"

Selain melakukan money politik, masyarakat juga diresahkan dengan adanya praktik perjudian dengan omset ratusan juta rupiah, hal ini nyata-nyata di larang dalam islam sebagaimana firman Allah SWT dalam surat al-Mâ'idah ayat 90:

30 Abd.Wahab al-Khalaf, Al-siyasah wa al-Syari'yah, hlm. 15. dalam program kitab digital alMaktabah asy-Syamilah, versi 2.09 .

31 Ibnul Qayyim Al Jauziyah, Al Thuruq Al-Hukmiyah Fi Siyâsat Al-Syarliyah, Tahqiq Basyir Muhammad Uyun,hlm, 26 dalam program kitab digital al-Maktabah asy-Syamilah, versi 2.09.

32 A.Djazuli, Fiqh Siyasah:Implementasi Kemaslahatan Umat dalam Rambu-rambu Syariah .Jakarta: Kencana 2009), 29. 
Hai orang-orang yang beriman, Sesungguhnya (meminum) khamar, berjudi, (berkorban untuk) berhala, mengundi nasib dengan panah, adalah Termasuk perbuatan syaitan. Maka jauhilah perbuatanperbuatan itu agar kamu mendapat keberuntungan.

Selain itu masyarakat dibuat ketakutan dengan adanya tekanan-tekanan/intimidasi yang dilakukan oleh para tim sukses calon kepala desa daleman terhadap rakyat dengan berbagai cara, sehingga masyarakat takut karna ada yang megancam akan dibunuh jika ia kalah, hal ini sangat bertentangan dengan nilai dasar figh siyâsah syar'iyyah yang di kemukakan oleh pernyataan Ibnu Qoyyim, yang menyatakan bahwasanya siyâsah syar'iyyah adalah siyâsah yang mengacu pada syara' dalam mekanisme pengendalian dan pengarahan kehidupan umat, terkait keharusan moral dan politik untuk senantiasa mewujudkan keadilan, kerahmatan, kemaslahatan, dan kehikmahan. ${ }^{33}$

Esensi siyâsah syar'iyyah yang bermakna pengaturan urusan pemerintahan kaum muslimin secara menyeluruh dengan kiat-kiat yang dapat mewujudkan kebaikan (mashlahat) serta mencegah terjadinya keburukan (mafsadah), dengan tetap menjaga batasanbatasan syar'i dan prinsip-prinsipnya secara umum, meskipun tidak secara nash, serta perkataan para imam ahli ijtihad. ${ }^{34}$

Dari sini, diketahui bahwa siyâsah syar'iyyah disamping berpegang dengan dalil yang tegas, juga berpijak pada maslahah mursalah, yaitu suatu maslahat di mana tidak didapati dalil secara tegas baik yang memerintahkan maupun yang melarang.

Secara teoritis, perinsip kemaslahatan adalah, sebagaiaman dikemukakan oleh Rachmat Syafi'i yaitu :

a) Melihat kemaslahatan yang terdapat dalam kasus yang dipersoalkannya;

b) Melihat sifat yang sesuai dengan tujuan syariat yang mengharuskan adanya ketentuan hukum agar tercipta suatu kemaslahatan; dan

33 Ibid., 28

${ }^{34}$ Ruwaifi' bin Sulaimi, Memaknai Politik Syar'l, Majalah AsySyariah Edisi 049.

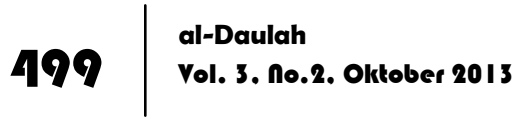


c) Melihat proses penetapan hukum terhadap suatu kemaslahatan yang ditunjukkan dalil khusus. Dalam hal ini adalah penetapan suatu kasus bahwa hal itu diakui sah oleh salah satu bagian tujuan syariat Islam. ${ }^{35}$

Adapun syarat-syarat kemaslahatan adalah :

a) Berlaku secara khusus untuk urusan muamalah karena masalah ibadah beralaku tetap dan tidak berubah-ubah;

b) Tidak berlawanan dengan maksud syariat atau salah satu dalil yang sudah dikenal; dan

c) Maslahat karena kepentingan yang nyata dan diperlukan oleh masyarakat. ${ }^{36}$

Tinjauan Peraturan Daerah (PERDA) Kabupaten Sampang No.5 Tahun 2006 tentang Tata Cara Pelaksanaan Pilkades.

Sebagaimana telah diuraikan tentang pentingnya kedudukan kepala desa, maka proses pergantian kepala desa ini tentunya merupakan peristiwa besar bagi masyarakat desa. Artinya penting pergantian kepala desa tampak jelas dari reaksi-reaksi yang muncul yang dilakukan penduduk desa pada saat proses pemilihan kepala desa berlangsung.

Dalam usaha memenangkan pemilihan tersebut, maka masing-masing calon akan menggunakan cara-cara tertentu untuk memproleh dukungan suara, banyak cara yang di gunakan oleh seorang calon kepala desa untuk mendekati tetangga-tetangganya. Sebaliknya, penting untuk diketahui atas dasar apa para tetangga mendukung atau tidak mendukung pencalonannya. Hal yang serupa tentu terjadi pula dalam lingkungan pekerjaan, lingkungan kekerabatan maupun dalam lingkungan pergaulan lain dari calon kepala desa.

Dalam hal proses dan mekanisme pemilihan kepala desa daleman mulai dari pembentukan panitia pemilihan kepala desa (P2KD), penjaringan bakal calon kepala desa, kampanye,

\footnotetext{
${ }^{35}$ Rachmat syafi'l, I/mu Ushul Fiqh (Bandung: Pustaka Setia 1999), I 18.

${ }^{36}$ Hanafi, Ushul Figh (Bandung:Al-Ma'arif, 1989), 144.
} 
pemunggutan dan perhitungan suara, sampai pengumuman dan penetapan calon terpilih, panitia pemilihan sudah melakukan prosedur berdasarkan Peraturan Daerah (PERDA) Kabupaten Sampang No.5 Tahun 2006 Tentang tata cara pencalonan, pemilihan, pelantikan dan pemberhentian kepala desa.

Namun dalam pelaksanaanya ada beberapa oknum baik dari warga maupun salah satu calon yang melakukan bentuk pelanggaran, seperti : politik uang, intimidasi dan praktek perjudian. Dalam hal ini praktik tersebut tidak dibenarkan jika di tinjau dari Pasal 15 Perda Kabupaten Sampang No.5 Tahun 2006. Yaitu dalam Pelaksanaan mencari dukungan dan kampanye tidak dibenarkan dalam bentuk:

a. Pawai atau arak arakan;

b. Pemberian uang, barang dan fasilitas lain;

c. Pemasangan foto, tanda gambar, slogan-slogan dan lain-lain, diluar radius 100 (seratus) meter dari rumah calon yang berhak dipilih;

d. Melakukan intimidasi terhadap pemilih.

Sejauh mana cakupan makna pemberian uang yang dilakukan melalui tim sukses masing-masing calon dalam mencari dukungan. Sebagaimana keterangan salah satu warga bahwasanya mereka diberi uang pada saat malam hari, 1 suara dihargai seratus ribu sampai tigaratus ribu. ${ }^{37}$

Begitu juga dengan intimidasi yang dilakukan oleh orangorang suruhan salah satu calon, dibuktikan dengan penuturan salah satu warga (ibu haimah) yang ditakut-takuti akan kehilangan sapi jika tidak mau memilih calon yang mereka unggulkan. Dengan mendapatkan tekanan / Intimidasi tersebut ia rela memilih yang tidak sesuai dengan hati nuraninya.

Pelaksanaan Pilkades juga diramaikan para petaruh dan penjudi dari baik warga desa setempat sendiri, atau juga dari warga desa lain yang sengaja dating untuk mengadu 
keberuntungan dengan praktik perjudian karena taruhannya, tak tanggung-tanggung, selain uang, sepeda motor bahkan mobil. Sejumlah oknum kepala desa juga ada yang ikut ambil bagian meramaikan pasar taruhan, praktik perjudian ini merupakan kondisi yang mencederai pesta demokrasi desa meski masalah perjudian ini belum di atur dalam Perda tersebut. ${ }^{38}$

Mekanisme dan standar baku dalam pemrosesan mesti dipatuhi untuk meredam protes dan konflik yang rawan muncul akibat praktik perjudian. Di sinilah kredibilitas panitia dipertaruhkan.

Selain itu, aspek perjudian yang mengiringi Pilkades adalah realitas yang tidak terbantahkan. Nilai taruhannya yang menggunung itu bukan lagi rumor, tetapi sudah "cerita lama". Bahkan, ditengarai para penjudi memiliki kekuatan tersembunyi dalam memenggaruhi hasil Pilkades. Mereka memiliki trik tersendiri memanfaatkan momentum.

Praktik tersebut dianggap sudah biasa dan merupakan adat turun temurun, karena Pilkades bagi warga merupakan kegiatan desa setempat (diluar kegiatan pemerintah) karena dana dan panitia pelaksana di lakukan oleh warga sendiri. Tidak dipungkiri secara historis bahwa Pilkades merupakan salahsatu Pemilu langsung di Indonesia. Tetapi dalam perjalanannya justru Pilkades menjadi sistem pemilihan yang paling statis dan tradisonal. Seakan menjadi anak tiri dalam kesatuan sistem pemilihan umum di Indonesia. Bahkan dibanyak desa diberbagai daerah di Indonesia termasuk di madura, biaya pemilihan kepala desa dibebankan kepada para calon kepala desa. Padahal pemilihan kepala desa adalah agenda pemerintah yang seharusnya dibiaya dari anggaran negara/daerah. Hal ini bisa jadi penyebabnya mereka melakukannya dengan terang-terangan, sebagian mereka mengaku belum tahu tentang larangan praktik tersebut. ${ }^{39}$

\footnotetext{
${ }^{38}$ Aliyanto (Ketua P2KD), Wawancara, Sampang, 25 Mei 2012.

${ }^{39}$ Jun, Wawancara, Sampang, 30 Mei 2012.
} 


\section{Penutup}

Proses dan mekanisme pemilihan Kepala Desa Daleman mulai dari pembentukan Panitia Pemilihan Kepala Desa (P2KD), penjaringan bakal calon kepala desa, kampanye, pemunggutan dan perhitungan suara, sampai pengumuman dan penetapan calon terpilih, panitia pemilihan sudah melakukan prosedur yang tidak bertentangan dengan Syara' atau Siyâsah Syar'iyyah (Sistem Politik Islam) namun dalam pelaksanaan ini salah satu calon melakukan praktik politik uang yang mana hal ini dilarang menurut syara' sebagaimana Hadist yang melarang terhadap praktik suap-menyuap. Dan prakrik intimidasi yang menyalahi nilai dasar siyâsah syar'iyyah tentang kemaslahatan. Selain praktik politik uang dan intimidasi, Pilkades juga di warnai dengan perjudian yang dalam al-Qur'an surat al-Mấ'idah ayat 90 praktik tersebut dilarang.

Praktik politik uang dan intimidasi menurut Peraturan Daerah (PERDA) Kabupaten Sampang No.5 Tahun 2006 tentang tata cara pencalonan, pemilihan, pelantikan dan pemberhentian kepala desa hal ini tidak dibenarkan jika dilihat dalam Pasal 15 Poin $b$ (Pemberian uang, barang dan fasilitas lain) dan Poin $d$ (Melakukan intimidasi terhadap pemilih). Sedangkan masalah perjudian yang mewarnai pilkades belum di atur dalam perda tersebut.

\section{Daftar Pustaka}

Aliyanto (Ketua P2KD). Wawancara, Sampang, 25 Mei 2012.

Budiardjo, Meriam. Demokrasi di Indonesia. Jakarta: Gramedia Pustaka Utama, 1996.

Depag. Al-Qur'an dan Terjemah. Bandung: PT. Syamil Cipta Media, 2005.

Djazuli, A. Figh Siyasah: Implementasi Kemaslahatan Umat dalam Rambu-rambu Syariah. Jakarta: Kencana 2009.

Hanafi. Ushul Figh. Bandung:Al-Ma'arif, 1989. 
Ibnu Taimiyah. Siyasah Syar'iyah. Surabaya: Risalah Gusti, 1995.

Jauziyah (al-), Ibnul Qayyim. Al Thuruq Al-Hukmiyah Fi Siyâsat Al-

Syar'iyah. Tahqiq Basyir Muhammad Uyun,hlm, 26 dalam program kitab digital al-Maktabah asy-Syamilah, versi 2.09.

Jun. Wawancara, Sampang, 30 Mei 2012.

Kampanye, Teori. http://all-about-theory.blogspot.com (15 Juni 2012.

Kampanye. http://id.wikipedia.org (15 Juni 2012).

Ketua P2KD (aliyanto). Data, Sampang, 10 Mei 2012.

Ketua P2KD (aliyanto). Wawancara, Sampang, 9 Mei 2012.

Khalaf, Abd. Wahab. Al-siyasah wa al-Syari'yah. dalam program kitab digital al-Maktabah asy-Syamilah, versi 2.09.

Latif, M. Syahbudin. Persaingan Calon Kepala Desa di Jawa. Jakarta : Media Pressindo, 2000.

Nurcholis, Hanif. Pertumbuhan \& Penyelenggaraan Pemerintahan Desa. Jakarta: Erlangga, 2011.

Pardi. Wawancara, Sampang, 20 Mei 2012.

Pasal 53 PP Nomor 72 Tahun 2005 Tentang Desa.

Pawi. Wawancara, Sampang, 27 Mei 2012.

PERDA Kab.Sampang No.5 Tahun 2006

Sali. Wawancara, Sampang, 26 Mei 2012.

Suharni, Sartono Kartodirdjo, Pesta Demokrasi di Pedesaan: Studi Kasus Pemilihan Kepala Desa di Jawa Tengah dan DIY. Yogyakarta: Aditya Media, 1992.

Sujamto. Otonomi Birokrasi Partisipasi. Semarang:Dahara Prize, 1992.

Sulaimi, Ruwaifi' bin. Memaknai Politik Syar'i. Majalah AsySyariah Edisi 049.

Surianingrat, Bayu. Pemerintahan Administrasi Desa dan Kelurahan. Jakarta : Rineka Cipta 1992.

Syafi'i, Rachmat. Ilmu Ushul Figh. Bandung: Pustaka Setia, 1999.

Syamsudin, Haris. Desentralisasi \& Otonomi Daerah. Jakarta: LIPI

Press, 2007. 
Thoha, Miftah. Birokrasi \& Politik di Indonesia. Jakarta: Rajawali Pers, 2003.

Usairy (al-), Ahmad. Sejarah Islam: Sejak Zaman Nabi Adam Hingga Abad XX. Jakarta: Akbar Media Eka Sarana. 2003.

UU No. 32 Tahun 2004 Tentang Pemerintah Daerah. Jakarta : Sinar Grafika, 2005.

Wahyu, Ramdani. ISD (Ilmu Sosial Dasar). Bandung: Pustaka Setia 2007. 